\title{
I Never Thought a Stare Would Change My Life
}

\section{Erika Yesenia Rodriguez Carreño}

The day I saw him for the first time, I was completely paralyzed because of his dazzling beauty. I thought he was the most handsome man I had ever seen. He was tall, his eyes were green, and his face was so sweet. His beautiful smile accompanied by his dimples illuminated the whole place. I could not help smiling flirtatiously because at least I expected a glance in return. Although, I assumed that someone like him would never notice me, I did not care. I kept looking at him. I looked like a complete fool; however, to my surprise, he looked back at me smiling. I felt like the happiest woman in the world. It was amazing how his gaze had enchanted me so much that I did not know what to say. My face reflected the inevitable attraction I had for that handsome man. I do not know what happened to me. I had never felt those strange butterflies in my stomach. It is something very difficult to explain, and at the moment, I just thought I wanted to see him again.

Fortunately, the day I could see him again was not long to come. As was customary, every year there was a football match between different municipalities; it was on that occasion when I knew that the person who had stolen my heart did not live far from me. That day, his town would play against mine; for that reason, the sports center was divided into two parts. At one end, all the people from La Uvita sat and, in the other end, all those from 


\section{ENRETALUA Douman}

Boavita. As it was my fortune, we both sat sitting in the same direction, so it was inevitable to not look at him, right? It was the best thing that could have happened to me. Throughout the game we did nothing but look at each other and smile, adding that occasionally, he tried to be funny, imitating everything I was doing. All this filled me with joy because I knew that possibly I liked him too. Anyway, that night we did not say anything, but for me, his bright eyes told me a lot.

The next day, I went out with some friends and sat in the same place as the night before. I kept hoping to see him again and, as expected, he arrived there. We never agreed to meet, but maybe it was destiny putting us in front of each other again. I remember other girls flirting with him, and he seemed to answer back with his silly smile. Yes! I admit that I was a little jealous, and I do not understand why. Unfortunately, he was only a stranger, but Id id not know that I would be surprised a few minutes later.....

Mysteriously, one of the girls who was flirting with him approached and handed me a gift with a note that said, "The heart has reasons that reason will never understand." How was it possible that they were so brazen? Why were they giving me this gift? It was obvious that he had given it to her, and she wanted me to keep it. I was totally frustrated, angry, and at the same time resigned because at that moment I confirmed that someone like him would never notice me. Immediately, I decided to return the gift, but everyone looked at me surprised. Now, I understood less; that's why Ana María, the person who had given me the gift, explained that this present had been sent to me. Was this real? I remained immobile to such an affirmation. I really did not know what to say or what to do. However, the inevitable change of color on my face reflected my sorrow. That night we could not talk since he had to travel to his town.

When I arrived at my house I could not stop smiling. I think I was in love as I had never 
felt so special, so important, and loved by someone. In fact, I looked like an excited girl. During the day, I did nothing but count the hours anxiously waiting for 7 p.m. because I knew that I would see him in the same place again. Finally, the time arrived and indeed, he was there waiting for me. Even though we were both a bit shy, he looked at me, and we agreed to meet outside. We sat on a park bench and started asking each other questions about our lives. I remember it was a perfect night. The moon was so beautiful and so big; the place was only for us, and the silence of the night was our only company. Everything was perfect. The hours passed, and I remembered that it was too late. Then, I wanted to leave, but he did not let me go because he wanted to tell me something. Nonetheless, the words could not come out of his mouth because of his sorrow. It made me laugh because I already knew what he wanted to say. Suddenly, his face changed colors and his hands started to sweat. He was really nervous, so he asked me to help him say his proposal. Then, he started saying... "Do you want... (I continued)... to be... (And he finished)... my girlfriend?” I knew that I had just met him, but I could not refuse such a proposal. Without even thinking about it, I accepted. From this moment, my story began.

Ender and I wanted to share every moment together. After school, he came to my house every day. I was so lucky because he was the first boy my parents had accepted. I had never been so happy; he was my perfect complement. We understood each other very well. In fact, I thought he was the man of my life. In this way, we innocently talked about our perfect future without knowing what would soon happen.

It did not take long for our happiness to turn into sadness. However, today I am sure that things have their reason for being. One day, when our feeling was stronger than ever, his parents made a decision that would change our lives. They suddenly decided to leave this country. It was a very unexpected and painful news for both of us. Even though our hearts were completely 


\section{ENLETAULA Doumboal}

destroyed, neither destiny nor anybody was going to prevent us from continuing this amazing love story. It was then that he promised me that he would come back in three months, and he would call me every day. Finally, it was time to say goodbye and impotence took over me when I saw the love of my life move away. Anyway, I only hoped to believe he would return one day. People say that time heals wounds, but this was not case. Every day, I missed him more. There was not a single moment in which I did not think about him, and in this way, three months went by. Finally, the awaited moment arrived, and I was there waiting for the return of a boy, who in spite of filling my life with happiness, would also be in charge of giving it a different direction. It is true that he was leaving everything to be with me, he showed that he loved me with all his heart. Yet, we also have to be aware that what we call love at some point in our lives, may turn out to be a simple caprice of which there will be nothing but repentance.

A few days before beginning college, I was so sick that in just one week I lost $7 \mathrm{~kg}$. For that reason, I needed to go to the doctor without knowing exactly what was happening to me. However, the news I received was not what I expected. I was pregnant, and that was the result of our fight and stubbornness to want to be together. Well, it was true that with our young age and inexperience, it would be a really difficult task. Despite the fear and anguish that it caused me to accept the news, I had to be responsible and mature. Now there was only one problem, a very big problem...my dad's reaction. Yes! When he knew that soon he was going to be a grandfather, my dream of studying would not come true.

Regardless of others' opinions, I decided to go ahead and follow my dream of studying. However, the support I expected from the "man of my dreams" gradually disappeared, as did the image of a perfect gentleman. Even my pregnancy could not prevent him from disrespecting me whenever he wanted. His preferences began to change. Now, he wanted to drink, hang out with 


\section{ENLETAULA Doumboal}

his friends, and drive his motorcycle. He wanted to do everything except be with his family. I

confess that I was tired of this situation, who wouldn't be? I had changed the love of my parents

for the contempt of a man, but I did not feel able to leave him. In spite of everything, I still loved him like the first day.

Over time, many things happened. My beautiful daughter was born, and her company alleviated my loneliness a little; however, our family situation remained the same or at times worse. One day, I heard a rumor that caused me great anxiety; a group of men were robbing and extorting in the village. This was really a novelty since the village was known for its tranquility. That's when I began to suspect the things that mysteriously appeared in our house. I had to know the truth; therefore, I started looking for some clues that would give me the answer. As expected, I found a dagger, then a gun, and finally a shotgun. At that moment, I was confirming my hunches, which out of fear I had not wanted to acknowledge. My daughter's father had become a delinquent, and I was living with him. In any case, the only thing I knew was that sooner or later the truth would be revealed.

The next day, with great pain in my heart, I decided to talk to him. He, with his despotism, denied everything. It was hard to accept that cruel reality because I knew that nothing could change it. That same afternoon, policemen knocked on my door. They were asking for Ender, but I did not know anything about him since that morning. Suddenly, the wife of one of his friends arrived crying. At that time, I thought the worst, possibly they had died ... Later, the mayor also came to my house. He told us that Ender and his friends were prisoners. Anguish, despair, and sadness invaded me. It was incredible to recognize how life changed had changed us. We went from wanting to play to having a family at only 18 years of age. WE were young, but we had lived an experience that we would never forget. Finally, he was sentenced to thirteen 


\section{ENRETALUA Dousmoal}

years in prison for extortion, aggravated robbery, illegal bearing of arms, and conspiracy to

commit a crime. For these reasons, I insist that I never thought that a simple stare would change my life... 